Kepemimpinan Kepala Sekolah dalam Meningkatkan Kompetensi Guru

\title{
KEPEMIMPINAN KEPALA SEKOLAH DALAM MENINGKATKAN KOMPETENSI GURU
}

\author{
Dewi Susanti, Moh. Rois, Fartika Ifriqia
}

\begin{abstract}
Forward the retreat of an educational institution is very influential on the leader figure. In the principal education institution has an important role to advance the school in the lead. Basically education consists of several components that affect each other and related to each other. Of these components, the teacher who plays an important role and is the key to the success of education. For that the competence of a teacher should be improved. With the principal component of teachers and principals that play an important role for the advancement of education, the authors are interested to explore the leadership of principals in improving teacher competence, with the focus of research: 1) How the principal's efforts in improving teacher competence, 3) the principal's efforts in improving teacher competence?. From the research results can be concluded, that 1) Efforts principals in improving teacher competence. 2) Factors that support the principal's efforts in improving teacher competence. 3) Principal inhibiting factors in improving teacher competence.
\end{abstract}

Keywords: Principal Leadership, Teacher Competency

\begin{abstract}
ABSTRAK
Maju mundurnya suatu lembaga pendidikan sangat berpengaruh pada sosok pemimpin. Dalam lembaga pendidikan kepala sekolah mempunyai peran penting untuk memajukan sekolah yang di pimpinnya. Pada dasarnya pendidikan terdiri dari beberapa komponen yang saling berpengaruh dan berkaitan antara yang satu dengan yang lainnya. Dari komponen tersebut, gurulah yang memegang peran penting dan merupakan kunci pokok bagi keberhasilan pendidikan. Untuk itu kompetensi seorang guru harus di tingkatkan. Dengan adanya komponen kepala sekolah dan guru yang sangat berperan penting untuk kemajuan pendidikan, maka penulis tertarik untuk mendalami tentang kepemimpinan kepala sekolah dalam meningkatkan kompetensi guru, dengan fokus penelitian: 1) Bagaimana upaya kepala sekolah dalam meningkatkan kompetensi guru?, 3) Apa faktor penghambat usaha kepala sekolah dalam meningkatkan kompetensi guru?. Dari hasil penelitian dapat disimpulkan, bahwa 1) Upaya kepala sekolah dalam meningkatkan kompetensi guru. 2) Faktor yang mendukung usaha kepala sekolah dalam meningkatkan kompetensi guru. 3) Faktor penghambat usaha kepala sekolah dalam meningkatkan kompetensi guru.
\end{abstract}

Kata kunci: Kepemimpinan Kepala Sekolah, Kompetensi Guru

\section{PENDAHULUAN}

Pendidikan merupakan proses yang sangat menentukan untuk perkembangan individu dan masyarakat. Kemajuan suatu masyarakat dapat dilihat dari perkembangan pendidikannya. Dengan adanya perkembangan yang semakin maju di era globalisasi dan modernitas saat ini, peningkatan mutu pendidikan kiranya menjadi suatu masalah yang urgen.
Peningkatan mutu pendidikan diperlukan dalam pengelolaan organisasi pendidikan agar bergerak menuju satu arah. Pendidikan yang baik dan bermutu menjadi dasar pengembangan dan kemajuan selanjutnya. Oleh karena itu, menurut Zazin $(2011,5)$ pengelola pendidikan harus merespon berbagai kebijakan pemerintah dan keinginan masyarakat dalam rangka perbaikan mutu dengan kreatifitas, inovasi yang tinggi, dan strategi yang baik dalam 
konteks sistem (optimalkan semua unsur manajemen sekolah baik proses input maupun output).

Tugas dan tanggung jawab untuk mewujudkan sekolah yang bermutu tak lepas dari kompetensi kepala sekolah dalam memimpin dan mengelola lembaga. Di sisi lain bahwa kepemimpinan yang efektif sangat menopang kompetensi guru dalam keberhasilan suatu proses belajar mengajar, namun dipihak lain untuk mencari figur pemimpin yang efektif ini bukan hal yang sederhana.

Menurut Anwar (2007, 107) dalam menjalankan tugas sebagai pemimpin formal maka seorang kepala sekolah dihadapkan pada persoalan teknis sekolah serta dituntut untuk menjadi leader yang handal ditengah tim guru. Bila selama ini banyak pendapat menyatakan kompetensi profesionalisme guru di Indonesia relatif rendah atau kurang memadai, sebagai akibat langsung dari kesejahteraan guru. Tinggi rendahnya mutu pendidikan banyak dipengaruhi oleh kualitas proses pembelajaran yang dilakukan oleh guru. Untuk itu peningkatan kemampuan guru dalam mengelola kegiatan pembelajaran disekolah menjadi tanggung jawab kepala sekolah sebagai supervisor, pembina dan atasan langsung.

Berdasarkan latar belakang tersebut diatas, maka penulis merasa tertarik untuk mengkajilebih dalam terhadap permasalahan tersebut dan dituangkan dalam bentuk skripsi yang berjudul "Kepemimpinan Kepala Sekolah Dalam Meningkatan Kompetensi Guru".

\section{LANDASAN TEORI}

\section{Kepemimpinan Kepala Sekolah}

Menurut Wahyusumidjo $(2002,81)$ kepala sekolah yang berhasil apabila mereka memahami keberadaan sekolah Secara sebagai organisasi yang kompleks dan unik, serta mampu melaksanakan peranan kepala sekolah sebagai seorang yang diberi tanggung jawab untuk memimpin sekolah. keberhasilan kepala sekolah menunjukkan bahwa kepala sekolah adalah seorang yang menentukan titik pusat dan irama suatu sekolah. bahkan lebih jauh tersebut menyimpulkan bahwa keberhasilan kepala sekolah adalah keberhasilan sekolah. beberapa diantara kepala sekolah dilukiskan sebagai orang yang sebagai orang yang memiliki harapan tinggi bagi para staf dan para siswa, kepala sekolah adalah mereka yang banyak mengetahui tugas-tugas mereka dan mereka yang menentukan irama bagi sekolah mereka. Peran kepala sekolah antara lain:

a. Kepala Sekolah Sebagai Edukator (Pendidik)

Upaya-upaya yang dapat dilakukan kepala sekolah dalam meningkatkan kinerjanya sebagai educator, khususnya dalam peningkatan kinerja tenaga kependidikan dan prestasi belajar peserta didik dapat dideskripsikan sebagai berikut:

Pertama, mengikutsertakan guru-guru dalam penataran-penataran,

Kedua, kepala sekolah harus berusaha menggerakkan tim evaluasi hasil belajar peserta didik untuk lebih giat belajar

Ketiga, menggunakan waktu belajar secara efektif di sekolah,

b. Kepala Sekolah Sebagai Manager Manager menurut Gaspersz (2003, 201) adalah orang yang melakukan sesuatu secara benar. Kepala Sekolah Sebagai Administrator

c. Kepala Sekolah Sebagai Supervisor Supervisi merupakan menurut Mulyasa $(2006,111)$ suatu proses yang dirancang secara khusus untuk membantu para guru dan supervisor dalam mempelajari tugas sehari-hari di sekolah.

d. Kepala Sekolah Sebagai Pemimpin/ Leader

Kepala sekolah sebagai leader harus mampu memberikan petuntuk dan pengawasan, meningkatkan kemauan tenaga kependidikan, 
Kepemimpinan Kepala Sekolah dalam Meningkatkan Kompetensi Guru

membuka komunikasi dua arah, dan mendelegasikan tugas. Seperti yang dikutip oleh Mulyasa $(2006,111)$ dalam bukunya Wahjosumidjo mengemukakan bahwa kepala sekolah sebagaia leader harus memiliki karakter khusus yang mencangkup kepribadian, keahlian dasar, pengalaman, pengetahuan profesional, pengetahuan administrasi dan pengawasan.

e. Kepala Sekolah Sebagai Inovator

Kepala menurut Mulyasa (2006, 111) sekolah sebagei inovator akan tercermin dari cara - cara ia melakukan pekerjaanya, secara konstruktif, kreatif, delegatif, intregatif, rasional, dan objektif, pragmatis, keteladanan, disiplin, serta adaptabel dan fleksibel.

f. Kepala sekolah sebagai motivator

Sebagai motivator, kepala sekolah harus memiliki strategi yang tepat untuk memberikan motivasi kepada para tenaga pendidik daan kependidikan dalam melakukan berbagai tugas dan fungsinga. Motivasi ini menurut Mulyasa (2006, 111) dapat ditumbuhkan melalui pengaturan lingkungan fisik, suasana kerja, disiplin, dorongan, penghargaan secara efektif, dan penyediaan berbagai sumber belajar melalui pengembangan Pusat Sumber Belajar (PSB).

\section{Kompetensi Guru}

Kesadaran akan kompetensi guru menuntut tanggungjawab yang berat bagi para guru itu sendiri. Dia harus berani menghadapi tantangan dalam tugas maupun lingkungannya, yang akan mempengaruhi perkembangan pribadinya. Berarti dia juga harus berani merubah dan menyempurnakan diri sesuai dengan tuntutan zaman.

Seorang guru profesional adalah orang yang memiliki kemampuan dan keahlian dalam bidang keguruan atau dengan kata lain ia telah terdidik dan terlatih dengan baik. Dalam perspektif kebijakan nasional, Musfah (2011, 59) menyatakan "pemerintah telah merumuskan empat jenis kompetensi guru, sebagaimana tercantum dalam penjelasan Peraturan Pemerintah No 16 Tahun 2007 tentang standart Nasional pendidikan, yaitu kompetensi pedagogik, kepribadian, sosial, dan profesional".

\section{METODE PENELITIAN}

\section{Pendekatan dan Jenis Penelitian}

Penelitian ini memusatkan pada kepemimpinan kepala sekolah dalam meningkatkan kompetensi guru. Pendekatan penelitian yang di gunakan dalam penelitian ini adalah pendekatan kualitatif. Yaitu prosedur penelitian menurut Moleong $(2002,4)$ yang menghasilakan data deskriptif berupa kata-kata tertulis atau lisan dari orang-orang dan perilaku yang diamati.

Sedangkan jenis penelitian yang digunakan dalam peneliti ini adalah studi kasus. Seperti yang dijelaskan Azwar $(2001,8)$, bahwa "studi kasus merupakan penyelidikan yang mendalam (indepth study) mengenai suatu unit sosial sedemikian rupa sehingga menghasilkan gambaran yang terorganisasikan dengan baik dan lengkap mengenai unit sosial tersebut".

Untuk itu pada kesempatan ini peneliti dalam memperoleh data yang semaksimal mungkin yang lebih mendalam, yang ditempuh melalui pendekatan kualitatif karena prosedur penelitian ini akan mendeskripsikan atau menggambarkan secara umum tentang Kepemimpnan Kepala Sekolah Dalam Meningkatkan Kompetensi Guru.

\section{Data dan Sumber Data}

Data dalam penelitian ini adalah semua data dan informasi yang diperoleh dari para informan. Dengan langkah memgekplotasi jenis data kualitatif yang terkait dengan masing-masing fokus penelitian yang sedang diamati. Sumbernya diperoleh dari Kepala Sekolah, wakil kepala sekolah, para dewan guru, serta sumber-sumber lain yang dimungkinkan dapat memberikan informasi. 
Selain itu data penelitian juga bersumber dari dokumen-dokumen yang ada di Madrasah.

\section{Pengumpulan Data}

Untuk memperoleh data di lapangan dalam rangka mendiskripsikan dan menjawab permasalahan yang sedang diteliti dipergunakan metode pengumpulan data sebagai berikut:

\section{Metode Wawancara}

Dalam penelitian ini wawancara dilakukan terhadap; kepala sekolah guna mencari data tentang cara tentang cara menggerakkan orang lain agar secara sadar dan sukarela melaksanakan kewajibannya secara baik sesuai dengan yang diharapkan pimpinan dalam rangka mencapai tujuan, pembaharuan-pembaharuan terhadap pelaksanakan pendidikan disekolah yang dipimpin berdasarkan prediksiprediksi yang telah dilakukan sebelumnya, contohnya inovasi berupa pembaharuan kurikulum dengan memperhatikan potensi dan kebutuhan daerah tempat madrasah tersebut berada, peningkatan kompetensi guru.

\section{Metode Observasi}

Peneliti menurut Suharsono (1995, 70) melakukan pengumpulan data dengan cara mengadakan pengamatan dan pencatatan secara sistematis tentang gejala yang tampak pada subjek penelitian tetapi peneliti berada diluar subyek yang diteliti dan tidak ikut dalam kegiatan-kegiatan yang mereka lakukan.

Observasi ini digunakan untuk menghimpun data tentang situasi dan kondisi di Madrasah, baik mengenai sarana dan prasarana yang ada, mengamati struktur organisasi, maupun untuk melibatkan langsung dari dekat untuk mengadakan pengamatan dan pencatatan kegiatan serta aktivitas subyek.

\section{Dokumentasi}

Metode dokumentasi dipergunakan untuk melengkapi metode observasi dan wawancara, dan mengumpulkan data dari non insani misalnya data yang diperoleh dari catatan, transkrip atau rekaman.

Maimun $(2005,54)$ menjelaskan metode dokumentasi merupakan "suatu metode yang digunakan untuk mengumpulkan data yang bersumber dari selain dan kata-kata".

\section{Analisis Data}

Analisis data menurut Kasiran (tt, 353) merupakan proses mensistematiskan apa yang sedang diteliti dan mengatur hasil wawncara seperti apa yang sedang diteliti dan mengatur hasil wawancara seperti apa yang dilakukan dan di pahami dan agar supaya peneliti biasa menyajikan apa yang di dapatkan pada orang lain. Dalam melakukan analisis data digunakan beberapa langkah yaitu.

1. Reduksi data

2. Penyajian Data (Display)

3. Penarikan Kesimpulan (conclusi data)

Selain itu penarikan kesimpulan merupakan kegiatan penyimpulan maknamakna yang muncul dari data yang diuji kebenaranya.

\section{PEMBAHASAN}

Setelah melakukan observasi dan wawancara mendalam peneliti menemukan bentukbentuk upaya kepala sekolah di lapangan, sebagai berikut :

\section{Upaya Kepala Sekolah dalam Meningkatkan Kompetensi Guru}

Berdasarkan hasil pengamatan yang dilakukan penulis yaitu dengan cara wawancara, observasi, dan dokumentasi dapat diketahui bahwa dalam meningkatkan kompetensi guru melalui memberikan pembinaan, pelatihan-pelatihan dan aktif dalam musawaroh guru mata pelajaran (MGMP).

1. Memberikan pembinaan

Secara umun pembinaan yang dilakukan kepala sekolah dengan memberikan kiatkiat agar guru lebih giat, lebih semangat, 
Kepemimpinan Kepala Sekolah dalam Meningkatkan Kompetensi Guru

lebih disiplin lagi dari sebelumnya. Hal ini salah satu upaya kepala sekolah dalam meningkatkan kompetensi guru. Pemberian pembinaan dengan memberikan pengarahan baik mengenai keilmuan, tentang strategi, dan juga tentang etika/kesusilaan yang baik dengan pendidikan karakter agar guru menjadi uswah yang baik. dilaksanakan rapat setiap minggu dengan kepala sekolah dan waka kurikulum. Pembinaan dan pengembangan kompetensi guru, juga dilaksanakan melalui bentuk pendidikan dan pelatihan (diklat) antara lain seperti:

2. Pendidikan dan pelatihan

Pendidikan dan pelatihan menurut Rahrjo (2014) ini antara lain dapat dilakukan dengan:

a. In-house training (IHT). Pelatihan dalam bentuk IHT adalah pelatihan yang dilaksanakan secara internal di kelompok kerja guru, sekolah atau tempat lain yang ditetapkan untuk menyelenggarakan pelatihan.

b. Kemitraan sekolah.Pelatihan melalui kemitraan sekolah. Yaitu dengangan sekaolah berpristasi, Belajar jarak jauh. dengan menghadirkan instruktur dengan sistem pelatihan via internet.

c. Kursus singkat di perguruan tinggi atau lembaga pendidikan lainnya. Menyusun karya ilmiah, merencanakan, melaksanakan dan mengevaluasi pembelajaran, dan lain-lain.

d. Pembinaan internal oleh sekolah. Pembinaan internal dilaksanakan oleh kepala sekolah dan guruguru yang memiliki kewenangan membina,

e. Pendidikan lanjut. Pembinaan profesi guru melalui pendidikan lanjut di dalam maupun luar negeri. bagi guru yang berprestasi. Pelaksanaan pendidikan lanjut ini akan menghasilkan guru-guru pembina yang dapat membantu guru-guru lain dalam upaya pengembangan profesi.

3. Aktif dalam Musawaroh Guru Mata Pelajaran (MGMP)

Forum MGMP sangat berperan penting dalam upaya meningkatkan kompetensi guru, karena dalam forum MGMP para guru bisa saling sharing dengan sesama profesi guru yang mengajar mata pelajaran yang sejenis. Membuat program pengajaran (PROTA), program semester (PROMES), satuan pengajaran (SATPEL), dan rencana pengajaran (RP).

\section{Faktor Pendukung Dan Penghambat Upaya} Kepala Sekolah Dalam Meningkatkan Kompetensi Guru

a. SDM guru yang bagus dan komitmen tinggi yang dimiliki para guru

SDM guru berpengaruhi pada kinerja, karena guru yang kompeten, dan berkualitas, memudahkan upaya kepala sekolah dalam meningkatkan kompetensi guru.

b. Lingkungan yang mendukung

Adanya lingkungan yang mendukung yaitu input dari siswa yang terseleksi, sehingga memotivasi para guru untuk lebih meningkatkan kompetensinya. Selain itu lingkungan individu guru dan rasa kekeluargaan yang dimiliki kepada sesama pendidik. Kedua-duanya inilah yang menentukan perkembangan seseorang.

c. Sarana dan prasarana yang menunjang Fasilitas yang memadai berupa tempat yaitu perpustakaan dan berupa media yaitu buku pegangan siswa sehingga upaya kepala sekolah meningkatkan kompetensi guru menjadi mudah. Dengan adanya perpustakaan dan mushola untuk kegiatan belajar mengajar dan ketersediaan buku paket untuk siswa memiliki peran penting bagi guru dalam peningkatan kompetensi. 
Faktor Penghambat Upaya Kepala Sekolah Dalam Meningkatkan Kompetensi Guru

a. Karakter pribadi masing-masing guru yang berbeda. Faktor yang mempengaruhi pencapaian kinerja menurut Madyawati (2013) adalah "faktor kemampuan (ability) dan faktor motivasi (motivation). Pegawai yang memiliki kemampuan tinggi didukung oleh motivasi dari dalam diri dan lingkungannya akan mampu mencapai kinerja yang maksimal".

Sehingga dalam hal ini, kepala sekolah berupaya untuk menanamkan pendidikan karakter kepada para guru. Sehingga rasa kekeluargaan dan kebersamaan bisa terbentuk dengan baik.

\section{KESIMPULAN}

Berdasarkan uraian diatas dapat disimpulkan:

1. Memberikan pembinaan, arahan kepada guru untuk aktif dalam MGMP, dan pelatihan

2. Faktor pendukung dan penghambat upaya kepala sekolah dalam meningkatkan kompetensi guru.

- SDM yang bagus dan komitmen tinggi yang dimiliki oleh para guru

- Lingkungan yang mendukung

- Sarana dan prasarana

3. Faktor penghambat upaya kepala sekolah dalam meningkatkan kompetensi guru yaitu:

Faktor individu masing-masing guru yang berbeda karakter, dan ini hal manusiawi faktor dari dari luar terkait masalah dana bisa diusahakan karena madrawah ini didanai oleh negara. Sehingga menurut peneliti terkait faktor penghambat tidak ada masalah yang serius.

\section{DAFTAR PUSTAKA}

Anwar, Sumarsih, dkk, 2007, Kompetensi Guru Madrasah, Jakarta: Balai Penelitian dan Pengembangan Agama Jakarta.

Azwar, Saifudin, 2001, Metode Penelitian Kualitatif, Yogyakarta: Pustaka Belajar.

Gaspersz, Incent, 2003, Total Quality Management, Jakarta: Gramedia Pustaka Utama.

Kasiran, Moh., tt, Metodologi Penelitian Kualitatif dan Kuantitatif, Malang: UINMaliki Pres.

Madyawati, http://blogmadyawati. wordpress.com / $2013 / 04 / 11 /$ kompetensi-profesional-dankompetensi-kepribadian/ di akses pada tanggal 5 Mei 2014, jam 07.50.

Maimun, Agus, 2005, Study Tokoh, Yogyakarta: Pustaka Pelajar.

Moleong, Lexy J., 2002, Metodologi Penelitian Kualitatif, Bandung: Rosda Karya.

Mulyasa, E., 2006, Menjadi Kepala Sekolah Profesional, Bandung: Remaja Rosdakarya.

Musfah, Jejen, 2011, Peningkatan Kompetensi guru Melalui Pelatihan dan Sumber Belajar Teori Dan Praktik, Jakarta: Kencana Prenada Media Group.

Rahrjo, Mudji,"Pengembangan Kompetensi Guru" http://mudjiraharjo.com/ artikel/136-pengembangan-profesionalguru-2.html diakses pada tanggal 12 April 2014, jam 09.00

Suharsono, Irawan, 1995, Metodologi Penelitian Sosial, Bandung: Remaja Rosda Karya.

Wahyosumidjo, 2002, Kepemimpinan Kepala Sekolah, Jakarta: Grafindo Persada.

Zazin, Nur, 2011, Gerakan Menata Mutu Pendidikan, Yogyakarta: Ar-Ruzz Media. 